\title{
Seasonal rhythm of development of Allium trautvetterianum in the Kulyab Botanical Garden
}

\author{
Shomurod Kullaev $^{1 *}$, Vera Cheryomushkina ${ }^{2 \dagger}$, and Mariyo Boboev ${ }^{3 \ddagger}$ \\ ${ }^{1}$ Rudaki Kulyab State University, 735360 Kulyab, Tajikistan \\ ${ }^{2}$ Central Siberian Botanical Garden SB RAS, 630090 Novosibirsk, Russia \\ ${ }^{3}$ Khatlon Science centre AS RT 735360 Kulyab, Tajikistan
}

\begin{abstract}
The article deals with the seasonal rhythm of development of the bulbaceous acrosympodially accreting polycarpic Allium trautvetterianum Regel (the subgenus Melanocrommyum) when growing in the Kulyab Botanical Garden of the Khatlon Scientific Center, Academy of Sciences of Tajikistan in 2010-2015. Duration of vegetation and phenological phases is described. The species is characterized on the phenorhytmotype as a shortgrowing ephemeroid. Influence of weather conditions on duration of phenological pahses is shown. It is established that the rhythm of development completely corresponds to the eastern variant of Mediterranean climate.
\end{abstract}

\section{Introduction}

Seasonal rhythm of development of plants is a representation of their life cycle which is shown in repetitive phenophases. Study of phenophases is necessary for understanding for plant community functioning [1]. The change in time and duration of the passage of phenophases to adjust to new conditions is one of the indicators of plant adaptation to changing environmental conditions. In the context of climate change, the importance of phenological study is currently increasing.

According to current data the genus Allium L. numbers about 900 species. Onions are widespread in the northern hemisphere and represent one of the largestgenera of the world flora [1]. The subgenus Melanocrommyum contains 170 species, the range of which is mainly restricted to the region of Ancient Meditarrenean [2]. Thirty one species of this subgenus grow in Tajikistan.

It is known that Melanocrommyum species on the rythm of development belong to ephemeroids. A short period of vegetation and duration of stay in dormancy as a bulb most of the year are typical of them [3,4]. Information on seasonal development of some onions of the subgenus Melanocrommyum is mainly availablein the works on introduction of them in different regions of Russia [4-6]; Uzbekistan [3]; the Ukraine [7]; and Germany [8].

\footnotetext{
* Corresponding author: kullaev_79sh@mail.ru

${ }^{\dagger}$ Corresponding author: cher.51@mail.ru

*Corresponding author: b_mario@mail.ru
} 
Although A. trautvetterianum Regel. has long been in use as a food and ornamental plant, its seasonal development pattern is not practically studied.

The aim of the work was study of the seasonal rhythm of development of $A$. trautvetterianum development in the Kulyab Botanical Garden (Southern Tajikistan).

\section{Material and methods}

Allium trautvetterianum is an endemic plant of the south-western Pamir-Alay, it grows in the semisavanna belt with domination of Prangos pobularia, Organum tyttanthum, Salvia sclarea, Hypericum scabrum, Taeniatherum asperum, Poa bulbosa, and Carex pachystylis, in the shibliak belt with domination of Pistacia vera, Crataegus pontica, and Amygdalus bucharica, and occurs at the exposure of vaiegated at an altitude of 700-1700 m above sea level.

The species has been cultivated in the Kulyab Botanical Garden since 1999 г. Onions were collected on the Dzhilantau Ridge (Temurmaliksky Region, Southern Tajikistan) [9]. Development of A. Trautvetterianum was observed durring 5 years from 2010 to 2015. Seasonal development was studied by the method of I.N. Beideman [10]. Duration of a concrete given phase was determined by development of 10-20 individuals per introduction population. Belonging to the phenorhythmotype was determined according to the I.V. Borisova classification [11].

The following phases of phenological development: vegetation, duration of functioning of the assimilation apparatus, growth of the flower stalk, budding, blooming, fruiting and dissemination were identified because of development pattern of onions as rosette plants .

Annual meteorological data of the research location were taken from the summaries of Kulyab weather station.

\section{Results and discussion}

I.G. Serebryakov [12] considered a seasonal rhythm of plant development to be one of the features reflecting adaptation to ecological-phytocoenotic and climatic conditions of growth.

The climate of Tajikistan generally belongs to the eastern variant of the Mediterrenean climate [13]. Kulyab and Kulyab Botanical Garden are located in southern Tajikistan at an altitude of $640 \mathrm{~m}$ above sea level in the valley of the Yakhsu River. Kulyab is characterized by insufficiantly humid climate, dry summer, moderately mild winter. The mid-annual air temperature is $16,4^{\circ} \mathrm{C}$, sometimes in summer it rises up to $44-46^{\circ} \mathrm{C}$, in winter, in certain years, it falls to $17-21^{\circ} \mathrm{C}$. Duration of the frost-free period is $260-309$ days, and the sum amounts to $5800-6000^{\circ}$. The period with temperature of more than $10^{\circ} \mathrm{C}$ lasts $240-250$ days. The effective heat sum for this period is $2800-3000^{\circ}$. In the hot season often blow dry southern winds in the form of dust storms. Large temperature changes are observed not only during a year, but also during a day. There is a lot of precipitation- $529 \mathrm{~mm}$, but its distribution is very uneven. Up to $70 \%$ of the annuak norm of precipitation falls in winter and spring [14]. Very little rain falls in summer. The period from June to September, at high air temperature, it is almost or rainless at all. The soil is dried out. Stable snow cover, only some centimeters, is formed very seldom.

Allium trautvetterianum is a perennial herbaceous, acrosympodially accreting, nonparticulating bulbous polycarpic plant. Annually unfolds one rosetted shoot consisting of a shortened part with 3 scale-shaped and 2-3 assimilative leaves and leafless flower stalk. The length of a flower stalk reaches $50 \mathrm{~cm}$. Leaves are lanceolate, upward, $2-3 \mathrm{~cm}$ wide, with an axil up to $3-6 \mathrm{~cm}$. A basal part of the shoot forms a tunicate ovate bulb $1,5-2,5 \mathrm{~cm}$ 
in diameter. The bulb is formed by membranous cover scale, storing scale, vaginate scale and axils of green leaves. Outside it is covered with greyish, almost papery splitting sheaths - leaf remnants of previous shoots. Additional roots are thin numerous, superficially arranged, develop on the bulb stem and are annually substituted by new ones. An inflorescence is dense many-flowered globe-shaped or umbellate thyrse. Like most species of the subgenus Melanocrommyum, it belongs to ephemeroids by the seasonal rhythm of development. A regeneration bud is laid in the bulb 3 years before development. Generative organs are completely formed by autumn previous to the growing season.

For 6 years of observations vegetation of A. trautvetterianum lasted from 71 to 81 days in the Kulyab Botanical Garden. However, vegetation periods differed substantially in various years. The earliest plant growing and emergence of the first leaves were noted in the first decade of February in 2010 and 2015, and the latest one - in the first decade of March in 2013-2014 (Fig. 1).

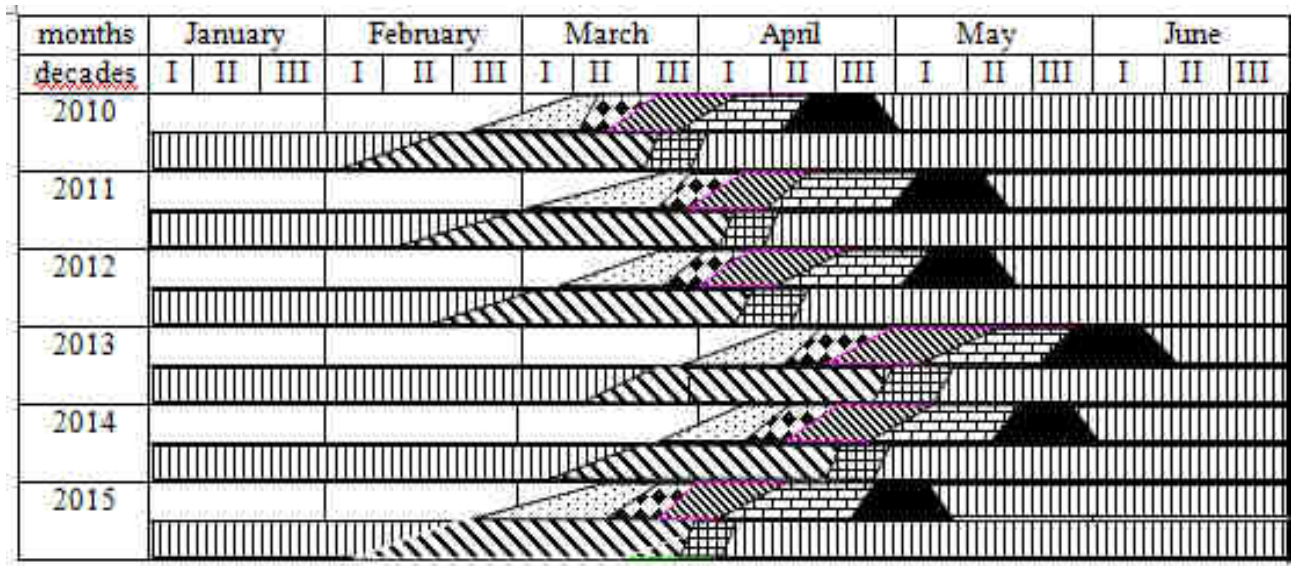

Fig.1. Phenological rhythm of Allium trautvetterianum Regel development in cultivation in 20102015.

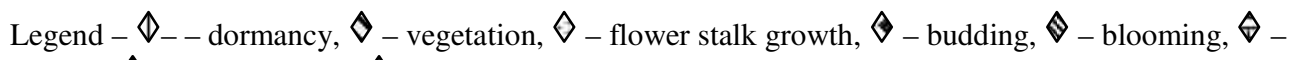
fruiting, $\nabla_{\text {- dissemination, }} \boldsymbol{\nabla}$-drying up of leaves.

Such a delay was linked with late onset of spring in 2013-2014 because of negative temperatures in February. This led to the shift of all phases of seasonal development on the later time in those years. In typical years the flower stalk of the generative shoot emerges 2-2.5 weeks after the beginning of vegetation (late February- early March). It increases in length throughout 15-20 days. A budding phase of a certain plant is short and does not exceed 5 days. Plants begin to bloom in mid-March at daily average temperature $+10^{\circ} \mathrm{C}$. Air temperature affects the beginning of blooming. So, the low daily average temperature $\left(+4,8^{\circ} \mathrm{C}\right)$ in March 2012 delayed transition of plants to flowering almost for 10 days. Duration of blooming of one flower is 5-8 days. The blooming period of plants in a population lasts 20-27 days. By its end leaves die off completely, but a flower stalk stays green. Seed ripening takes place during a month, general duration of this period fluctuates slightly and amounts to 15-20 days. Disseminations occurs in May, capsules open and seeds fall. As seeds are large, they turn out to be near the maternal plant. Not all capsules open by the moment of drying up of the flower stalk, their ripening occurs on the substrate after stalk lodging. Additional roots die off, and the plant as an onion enters into dormancy. In autumn, in late October-November in case of precipitation and at temperature higher 
than $+10^{\circ} \mathrm{C}$, roots begin to grow, but in contrast of development of typical Mediterranean species the vegetation is absent in A. trautvetterianum in autumn and winter and begins only in spring with the onset of stable positive temperatures.

Thus, A. trautvetterianum passes the full cycle of seasonal development in the Kulyab Botanical Garden.

Duration of vegetation and phenological phases in introduction depends on weather conditions of the year of observations. So late coming of spring as in 2012-2013 led to a shift of development phases almost for 20 days. The analysis of seasonal development pattern of A. trautvetterrianum showed that the growing period in the species under study began with the onset of temperature of $5-10^{\circ} \mathrm{C}$. By the nature of vegetation $A$. trautvetterrianum belongs to shortvegetating plants, ephemeroids. Its rhythm of development fully corresponds to the eastern variant of the Mediterrenean climate.

The work was carried out within the framework of the projects of State Assignments ГР № 01011ТД065 (Tajikistan) and № AAAA-A17-117012610053-9 (CSBG SB RAS, Russia).

\section{References}

1. A. J. Miller-Rushing, J. Weltzin, New Phyt. 184, 743-745 (2009)

2. E. Buisson, S. T. Alvarado, S. Le Stradic, L. P. Morellato, Restor. Ecol. 25, 164-171 (2017)

3. W. T. Stearn, The Kew bot. Mag. 9, 180-182 (1992)

4. R. M. Fritsch, A preliminary review of Allium subg. Melanocrommyum in Central Asia (IPK Gatersleben, Germany, 2016)

5. Z. N. Philimonova, Introdution and Acclimatization. 4, 91-99 (1966)

6. V. A. Cheryomushkina, Biology of Allium species in Evrasia (Nauka, Novosibirsk 2004)

7. O. V. Daeva, Ecology and Introduction Plants. 9, 110-114 (1963)

8. L. A. Tukhvattulina, L. M. Abramova Introduction of wild onions in Bashkortostan: biology, reproduction, agricultural techniques, use (Ufa, 2012)

9. P. E. Bulakh, Allium of the natural flora of Central Asia and their culture in Ukraine (Kiev, 1994)

10. K. Pistrick, The genus Allium - Taxonomic Problems and Genetic Resources (Gatersleben, Germany, 1992)

11. T. Boboev, M. Boboev, Sh. Kullaev. Medicinal and edible plants of Southern Tajikistan, as well as ways of their cultivation and protection (Kulyab, 2013)

12. I. N. Beydeman, Methods of studying the phenology of plants and plant communities (Moskow, 1974)

13. I.V. Borisova, Field geobotany. 4, 5-94 (1972)

14. I. G. Serebryakov, Bull. Mosc. Soc. of Natur. 69, 62-75 (1964).

15. N. N. Izmaylova, Deciduous xerophilic forests, light forests and shrubs (St-Peterburg, 1995)

16. Agroclimatic resources of the Tajik SSR (Leningrad, 1976) 